10 years ESJ

Special edition

\title{
Reclaiming the Body Through Tattoos
}

\author{
Sybele Macedo, MSc, PhD
}

Universidade Federal de Uberlândia, Brazil

Doi: 10.19044/esj.2021.v17n22p37

Submitted: 20 December 2020

Accepted: 24 January 2021

Published: 12 July 2021
Copyright 2021 Author(s)

Under Creative Commons BY-NC-ND

4.0 OPEN ACCESS

Cite As:

Macedo S. (2021). Reclaiming the body through tattoos. European Scientific Journal, ESJ, 17 (22), 37. https://doi.org/10.19044/esj.2021.v17n22p37

\section{Abstract}

Psychoanalysis has always addressed issues concerning the body. More recently, the proliferation of practices of aesthetic body intervention such as plastic surgery, piercings and tattoos have been calling the attention of psychoanalysts to their use and effects on the subject. This paper focuses on the analysis of the role of tattoos in reclaiming one's body, which will be approached through the psychoanalytical discourse analysis of data retrieved from online magazines and blogs. The practice of tattooing has subjective implications on the relationship between the body and the self, revealing a fundamental trace of human beings: the need to process traumatic events and give them some sort of tolerable expression.

Keywords: Body, Psychoanalysis, Tattoos

\section{Introduction}

In all regions of the world and in all ages, humans use their bodies as language, writing on the skin the history of their lives. Throughout history, bodily interventions such as tattoos and piercings have been given various statuses, from forbidden art to sacred rituals components or pagan bodily decoration. In the west, especially, those interventions were, for a long time, highly associated with social and economic marginality. Nowadays it is not rare to find bodies covered in ink or perforated by piercings, no matter the place, which indicates that such interventions have not only been gaining support but also becoming quite popular among people from all ages. 
The postmodern body has been constantly summoned to adapt itself to cultural norms and standards, as demonstrated by the industry of beauty, fitness and plastic surgeries. If piercings and tattoos were almost exclusively associated with marginality and with very specific groups like hippies, punks, sailors or criminals until the mid- $20^{\text {th }}$ century, it is now possible to perceive those bodily interventions as another form of socially accepted modification, distancing themselves from their transgressive character.

Those marks can be sported by the bodies as fashion accessories, new forms of creating beauty, modern talismans and even art. They can also display signs of rebellion, attachment to the past, to the family, to a place or even endurance to pain. They reveal an essencial trace of human beings: the need to process feelings and events giving them some sort of expression. The body is transformed into a manifest of the subject's life and the skin becomes a parchment where its history is written.

Drawing from Costa (2004), it is necessary to comprehend tattoos as more than a mere aesthetic matter. Although this might be the truth, in some cases, they are often more than that, they are bodily supports that are presented as forms of language that point to subjectivity and, therefore, are implied in identity matters constituting a mode of expression for the subject.

On that note, the aim of this paper is to analyze the use of tattoos as a way of reclaiming one's body after trauma and to try to articulate that with the psychoanalytical understanding of the body, drawing, mainly, from the works of Freud and Lacan. Stories on how getting a tattoo helped subjects overcome various issues that reflect on their self and body image are scattered all over the internet. From the famous and well known to the anonymous, those stories show how turning to ink can be a powerful way of taking ownership of a body that has, somehow, become disconnected from the subject. This paper is a result of an Internet Mediated Research, which means that the primary data were sourced from static, finished, published products available online, constituting an unobtrusive approach (Hewson, 2017). More specifically, it was collected from blogs and online magazines. The sample was selected through a thematically-related list of links connected to the object of the research. The data were, then, analyzed from a psychoanalytical perspective, founded on a psychoanalytical discourse analysis, which seeks to examine the linguistic and discursive mechanisms that are materialized in the texts here analyzed (Dunker, Paulon, and Milán-Ramos, 2016).

Psychoanalysis was chosen as the theoretical and methodological basis of this paper for its ability to give voice to the subject whilst it also allows the analyst to locate something singular that relates to the subject's jouissance and to the place it occupies in the world, taking the effects of its constitutive 
incompleteness under consideration, as well as the ethics of psychoanalysis in its capacity to preserve the lack as cause of the desire.

\section{A body beyond anatomy}

The idea of the body, as perceived by occidental culture today, was constructed throughout a long socio-historical process. This idea is due to the notion of a privatized subjectivity, typical of modernity, and must not be faced as an object made out of flesh and bones, but as an imaginary and symbolic construction. The appropriation of the body is something recent in west culture and psychoanalysis made a higher understanding of its drive dynamics possible by showing the effects of the unconscious, this other scene that constitutes and defines us beyond our conscious knowledge or control. The body dissected by anatomy, whose functioning is described by physiology, tells us nothing about the discourse that crosses the subject. In addition, it must be said that such discourse marks the difference between the biological body and the erogenous body that suffers and is, at the same time, subjected to jouissance ${ }^{1}$.

The body, from a psychoanalytical point of view, is not equivalent to the biological body focused by medicine and biology. It is not an organism, but an erogenous body, marked by unconscious desire and traversed by language. Freud, on his Studies on Hysteria (1893/1895/2006), contrasted the anatomical body with that which was the stage for the suffering of his hysterical patients, a body of jouissance. This body is not a primary reality as the organism; that is, the human baby is not born with a body, it has to build it, to manufacture it. This construction takes place in the baby's relationship with the Other, as well as with the others, and depends on operations that unfold in the imaginary and the symbolic, crossed by the real. The body, therefore, is a secondary reality, a "superstructure" inhabited by signifiers in which the drive seeks to inscribe itself.

The body is, at the same time, the origin and the stage of drive conflicts that the subject experiences as sensations. Anatomy is, then, a support for a body built from libidinal investments mediated by the phantasm. According to Freud (1923/2011), the self is linked to an image of the body and it is, first of all, a bodily self, a mental projection of a surface that enables the subject to inhabit the world and to relate to the others, distancing itself from them.

Even before being born, a child is subjected to language, intermediated by the Other, a place that is generally occupied by the mother or her substitute. This first and very close contact is what enables the configuration of the

\footnotetext{
${ }^{1}$ Jouissance is an enjoyment beyond the pleasure principle; an excess of life or vitality which shall not be correlated to any affect or emotion.
} 
psychic apparatus; that is, the establishment of the unconscious, the development of the self and the concomitant subjective constitution. The baby, at the moment of its birth, is nothing more than a piece of flesh, with biological needs that aim its survival. However, when the mother first offers her breast to this new baby, more than milk is offered. Along with the food, essential for survival, the baby has its first experience of pleasure while sucking the mother's breast and being sucked by it at the same time. What was once strictly in the realm of the instinct, of the physical and organic needs, gives place to the drive, defined by Freud (1915/2010) as a bordering concept between the psychic and the somatic.

The drive is a stimulus for the psychic, a constant force that, with the incidence of language designs the erogenous zones. These zones function as an anchorage and are located at the opening points of the organism; that is, in its orifices, places that allow communication between the body-organism and the world, between the inside and the outside.

The first months of the newborn are marked by autoeroticism, characterized by partial drives and by the experience of a body fragmented by the action of those drives, which originate and are satisfied within the same erogenous zone. The self is yet to be developed by the incidence of a new psychic force that will allow narcissism to be constituted (Freud, 1914/2010) Lacan (1949/1998) calls this new force the mirror stage and describes the behavior of a child in front a mirror and its joy in recognizing its image reflected on it. This operation is mediated by the symbolic and discursivized by the other, establishing the symbolic matrix where the self emerges. The feeling of a fragmented body gives place to a unified image of the body, enabling the emergence of a new psychic instance: the self (Freud, 1914/2010). The self is the mental projection of the body. It is as if the flesh and the psychic contents were wrapped by the skin promoting the constitution of a unified image of the self and allowing the child to enunciate in the first person singular, establishing a distinction between the self and the other.

The image of the self as a body is made up and cut out by language, by signifiers imposed on the baby even before its birth. It is the language that connects the fragmented body of autoeroticism and allows the articulation of the corporeal experiences of jouissance with the self, linking anatomy to image.

The body for psychoanalysis, as mentioned before, is not the same as the organism, the biological being. The human baby isn't born with a body, but it has to build it through psychic operations that are triggered by the relationship with the other's desire. These operations allow the baby to travel from a state of body fragmentation to a unified image of the self. The constitution of the self and the idea of it as a body are, thus, inexorably 
conditioned to a self-image that is given by the encounter of the baby with its image reflected in the mirror, mediated by the Other. This body is only sexualized because it offers itself to the gaze of the other. In this manner, narcissism can be understood as the constitution of an image able to be invested with libido. The body, a secondary instance, is an effect of the flesh, that is, the real, as well as of its image. This embodied flesh is articulated between the symbolic and the imaginary and takes the form of a narrative, a discourse, which makes it inaccessible to the subject in its totality. It is only possible for the subject to recognize its body when it is recognized by the gaze of the other. This gaze, withal, not only reflects the image of the subject as a body, but it also mirrors what this other expects, desires or demands from that image.

Because of the nature of the body as a secondary instance and its relationship with the gaze of the other, a mismatch is installed, generating a feeling of disagreement with one's own body. Originated from the imaginary and symbolic tying, traversed and constituted by the gaze of the other, this body is never fully grasped. Besides the changes caused by the real of the flesh, the subject also finds himself/herself captured by new images and new signifiers and has to constantly adjust to them.

There is an inseparable relationship between body and language. The speech resonates in the body, as long as it is sensitive to it. Because we are beings-in-a-body and, at the same time, the subject of the other's gaze, our body inevitably narrates our story and "integrates the meaning of our corporeity into our senses of who we are" (Lemma, 2010). The self is ultimately derived from bodily sensations, explains Freud (1923/2011), chiefly from those sensations springing from the surface of the body. It works as a physical map, a mental representation of the individual libidinized relationship with its body.

In virtue of the nature of the body, our self is in constant change. It is affected by the real that arises as an event and appears as modifications in the body due to the aging of the flesh, which the subject may not be able to control, such as the changes inflicted by puberty and old age. It is impressed by the way the gaze of the other focuses on the subject, gaze we are all dependent upon. Finally, the impositions of society regarding beauty patterns and traumatic situations that are unpredictable and, not rarely, irrational, also take their toll on the self and on the way the subject experiences its body.

Integrating the biological changes, dealing with the gaze of the Other and finding representation for traumatic situations in the symbolic are not easy tasks to tackle. For that reason, voluntary bodily transformations have always marked the relationship of the subject with his/her body. Self management strategies are part of our lives, from simply cutting one's hair to extreme 
makeovers that may include extensive cosmetic surgeries. The modification of the body, as Lemma suggests, "serves the primary function of managing unconscious anxieties and conflicts that may not be reflected upon" (2010, p.21). Tattooing the body, hence, may be a way of writing those changes on the body itself, reclaiming the subject's ownership upon it, (re)libidinizing and (re)constituting its borders by marking the flash and discursivizing it. Thus, the act of tattooing enables the self to regain consistency. As a consequence, such an act allows the body and the subject to circulate in society.

\section{A body of one's own}

According to psychoanalysis, the body is flesh and bones shaped into an image that is drawn and cut out by language. This image is made out of signifiers and sense, but also of some rest that digs a hole in the imaginary prosthesis that is the body and points to the impossibility of a total and full representation. There is always a mismatch between the imaginary projection we call the body and that which is the flesh, the organism, the anatomy. When we lose a representation that protects our body - which might happen due to various reasons such as the encounter with the real of the body that presents itself through the passage of time, when facing mental, physical illnesses or trauma, along with many other reasons - we need to rebuild the image of this body, reshape it and reorganize it into an erogeneity. It is from the outlined silhouette of the reality of the world that we differentiate ourselves from the others that inhabit it, establishing an interior and an exterior that allows the circulation of the social body.

In 2017, the 31-year-old actress and writer Lena Dunhan posted a series of pictures on her Instagram profile showing her recent tattoos. The tattoos were object of news, ${ }^{2}$ partly in reason of the captions accompanying them: "Been tatting myself up like crazy this month" [...] "I think it gives me a sense of control and ownership of a body that's often beyond my control, she wrote over the picture pf her new upper tight tattoo. Around the same time, Lena had been dealing with endometriosis, an often painful disorder in which the tissue that normally lines inside of the uterus - the endometrium - grows outside of it and might also involve the ovaries, fallopian tubes and the tissue lining the pelvis. ${ }^{3}$ This condition led Dunhan to five surgeries and put her through a great amount of pain. The actress was very open about her struggles and about how tattoos were helping her deal with them. As Todd wrote in her

${ }^{2}$ https://www.refinery29.com/2017/06/160884/lena-dunham-new-tattoos-body-ownershipendometriosis.

${ }^{3}$ https://www.refinery29.com/2017/06/160884/lena-dunham-new-tattoos-body-ownershipendometriosis. 
piece for Refinery29, "the tattoos are giving her a profound sense of agency over her own body."

The use of tattoos as way of dealing with the real of a body that somehow gets totally out of control making the gap between the imaginary prosthetic body and the flesh was not something new for Lena Dunhan. In an interview for HBO during one of the first seasons of her show, "Girls", Lena talked about her tattoos, constantly displayed on the show. She mentioned that when she reached puberty, she put on a lot of weight and felt as if she had completely lost control of her body. She claims that the tattoos helped her regain control over this body that was becoming larger, a body to which she could no longer identify with. It is as if she was trying to reclaim ownership of her own flesh and inscribe in the symbolic the changes she was going through.

Getting inked helped Lena deal with the real of the body, a body whose anatomy and functioning did not comply with its image and with the expectations she had over it, a body that quite often gets out of control and that needs to be reshaped in the imaginary and re-inscribed in the symbolic in order to make it possible for its owner to inhabit it.

I had always hated my body, a hatred which had expressed itself through starving and self-injury, but when I suffered episodes of sexual violence as an adult, I became entirely disconnected from it. I wanted to be as small and pure as possible so that it was easy to ignore, to feel it was not truly of me - that when somebody touched my body, they were not really touching me.

Nolan describes how the hatred she felt over her body was acted out through starvation and self-harming. She developed anorexia and her arms and upper legs were marked with razor cuts, an action she resorted to when her angst was overflowing. Her relationship towards her body aggravated after she suffered episodes of sexual violence as an adult, which led to a complete disconnection from her body. She no longer felt as if it belonged to her, when it was touched, it was as if someone else was being touched, not her. She describes the experience of getting her skin inked for the first time and the feeling of having her skin tattooed over old self-injury scars: "(...) in a moment my arms went from a site of grief to a site of joy". writes Nolan, who continues:

My tattoos calm the strange muddy feeling of disorientation I often get when I see my reflection. Now I look at them happily, smile at myself as I pass shop windows and catch a glimpse. They make me feel more confident than I really am. They make me feel myself. 
While Dunhan seemed to resort to tattoos in order to try to deal with the unruliness of her biological body, Nolan apparently found in them a way to reshape her imaginary body and redesign the image projection of herself. It seems that tattoos helped her re-actualize the mirror stage (Lacan, 1949/1998), rebuilding the prosthetic image for herself, allowing her to reclaim her body as her own, feeling reconnected to it and drawing pleasure from it. More than a way of reshaping the image of the body by intervening on the real of the flesh, tattoos may also be a way of discursivizing the anguish that plagues the subject and that may show itself in the form of symptoms, as Marc, quoted by Nolan, describes:

Essentially it's something commemorative, and to reshape my body. But it is also about turning something more abstract, like depression, into something physical and symbolic. I need to know that something can come from suffering. I often feel like I am not who I want to be, but tattoos are, even if just a small part. Plus I think they look boss.

Articulating trauma on the symbolic also appears in Deborah's story, quoted by Nolan:

I got a tattoo when I was 20 years old. I was having two or three full panic attacks a week and could barely leave the house. At a really young age I had been sexually abused and never treated for the trauma it caused. This left me with areas of my body where I could not be touched without violent and disgusted reactions. Getting a tattoo, particularly a silly one that only meant something because I like it was like reclaiming my territory.

Both Marc and Deborah's stories point to the use of tattoos as a form of language that is able to discursivize trauma in something other than words. Those marks appear as an attempt to represent the unrepresentable and to border the organism, constituting a body that is able to socially circulate. They may also be an attempt to buffer the fault that is constitutive of the subject. One must also think of the ways in which the tattoo - and other forms of bodily transformation - are inserted in the social bond, especially in the consumer society. While in the second half of the twentieth century the use of tattoos, piercings and reamers by adolescents and young adults was a sign of rebellion and identification of the counterculture and tribes of hippies, punks and bikers. In the 21 st century, it has clearly become a product, commonly associated with fashion and designer labels, embodied in the hands of famous tattoo artists. Its use has spread through all strata of society, establishing a profitable market in 
its surroundings and raising its status to that of an(other) object of consumption desired by young people and adults, from great centers to suburban areas. This character of tattoos and body transformation in general allows them to be socially accepted regardless of its use, while it may also disguise their psychic and cultural aspects as well as its function as a symptom.

\section{Final remarks}

The use of tattoos seems to designate some kind of support for the social circulation of the body, reshaping the drive circuit and libidinizing the body, which essentially means that this body may be represented for the other in the capture of its gaze. Although tattoos may help the subject get included in the symbolic, they do not replace completely the need for other representations. Nevertheless, they may constitute a territory that might become representational site, as Deborah and Marc's stories seem to point out. In all the self-narratives discussed in this paper, tattoos also seem to enable the passage from the body to a place where the subject can enunciate as "I". Those marks can be, then, bodily supports that tries to make up for the flaws in the mirror that lead to the non-recognition of one's own body, to the sense of disconnection from it that Marc, Deborah and Megan describe.

More than a way of reshaping the imaginary of the body intervening in the real of the flash, tattoos are a way of discursivizing the anguish that plagues the subject and may come out on the form of symptoms, as well as an articulation of trauma on the symbolic. The use of tattoos point to a form of language that is able to transform trauma trough something other than words. ${ }^{4}$

\section{References:}

1. Costa, A. (2004) A transicionalidade na adolescência. In: A. Costa (Ed.) Adolescência e Experiências de borda (pp. 165-193). Editora UFRGS..

2. Dunker, C. I. L. ; Paulon, C. P. \& Milán-Ramos, J. G. (2016) Análise Psicanalítica de Discurso - Perspectivas Lacanianas. Estação das Letras e Cores.

3. Freud, S. (2006) Estudos sobre a Histeria. Edição Standard das Obras Psicológicas Completas de Sigmund Freud. (Vol. II). Imago. (Originally published in 1893-1895)

\footnotetext{
4 This paper is a result of a research intership at The University of Sydney under the supervision of Prof. Natalya Lusty, PhD (University of Melbourne) and Prof. Lee Wallace, $\mathrm{PhD}$ (The University of Sydney), funded by CAPES -PDSE.
} 
4. Freud, S. (2011) O eи e o id. O eи e o id, "autobiografia"e outros textos [ 1923-1925]. Companhia das Letras, 2011. (Originally published in 1923)

5. Freud, S. (2010) O instinto e seus destinos. O inconsciente. Introdução ao narisismo; ensaios de metapsicologia e outros textos [1914-1916]. Companhia das Letras. (Originally published in 1915)

6. Freud, S. (2010) $O$ narcisismo. $O$ inconsciente. Introdução ao narcisismo; ensaios sobre metapsicologia e outros textos [19141916]. Companhia das Letras. (Originally published in 1914)

7. Lacan, J. O estádio do espelho como formador da função do eu. Escritos. Jorge Zahar Ed. 96-103.

8. Lemma, A. (2010) Under the skin. Routledge, 2010.

9. Hewson, C. (2017) Research methods on the internet. In: J. A. C. Danowski; L. Cantoni (Eds.) Communication and Technology: Handbook of Communication Sciences Series (HoCS). De Greyter Mounton.

10. Soler, C. (1984) The body in the teaching of Lacan. Translated by Lindsay Watson by wording of Guy de Villiers. First published in Quatro. 